pÿTeachers changing work and support needs from the perspectives of school leaders and newly qualified teachers in the Finnish context

Harju, Vilhelmiina

2018-10-20

pÿHarju , V \& Niemi , H 2018 , ' Teachers changing work and support needs from the perspectives of school leaders and newly qualified teachers in the Finnish context ' , European Journal of Teacher Education, vol. 41 , no. 5 , pp. 670-687 . https://doi.org/10.1080/02619768.2018.1529;

http://hdl.handle.net/10138/313956

https://doi.org/10.1080/02619768.2018.1529754

acceptedVersion

Downloaded from Helda, University of Helsinki institutional repository.

This is an electronic reprint of the original article.

This reprint may differ from the original in pagination and typographic detail.

Please cite the original version. 


\section{Teachers' changing work and support needs from the perspectives of school leaders and newly qualified teachers in the}

\section{Finnish context}

Teachers operate amidst continuous societal changes that transform schools. In response, teachers must acquire wide-ranging professional competences to work in complex school situations while cooperating with numerous partners both within and outside the school. This study examines how teacher growth and the new demands of the teaching profession appear from the perspectives of school leaders and newly qualified teachers. The aim is to investigate in which professional competences new teachers require support at the beginning of their careers. After presenting various theoretical reflections, we analyse the empirical data of Finnish school leaders $(N=104)$ and new teachers $(N=145)$ using quantitative and qualitative methods. The results indicate that new teachers particularly require support when working with diverse student groups and in order to provide holistic support for students' learning. New teachers also need support in facing conflict situations in schools and in working with partners, both within and outside the school community. The results provide important knowledge for the induction phase of teachers' careers.

Keywords: newly qualified teachers, school leaders, induction, professional development, professional competences, support needs 


\section{Introduction}

Policy-making reports and studies emphasising the importance of teachers' work in society have often analysed the evolution of teachers' work (e.g., Clandinin, Downey, and Huber 2009; European Commission/EACEA/Eurydice 2018; Schleicher 2012). The Council of the European Union (European Union 2014, 22) noted that:

\footnotetext{
in a fast-changing world, the role of teachers - and the expectations placed upon them - are evolving too, as they face the challenges of new skills requirements, rapid technological developments and increasing social and cultural diversity, and the need to cater for more individualized teaching and special learning needs.
}

Many such demands are linked with a growing diversity among students. Because students come from diverse backgrounds with variation in their knowledge and skills, teachers must know how to differentiate teaching in ways that will best support every student's learning. Emerging views of learning as collaborative and continuous construction process have set new objectives for education (e.g., Lonka et al. 2015; OECD 2017a) and transform perceptions and actions of the teaching profession. Teaching is increasingly collaborative work that involves colleagues within the school community, educational partners outside the school (parents in particular), and other experts and stakeholders who can help students in their learning (e.g., de Bruïne et al. 2014; Gartmeier, Gebhardt, and Dotger 2016; OECD 2017b; Vangrieken et al. 2015; Zeichner et al. 2016). The recent Communication from the European Commission on school development and excellent teaching (European Commission 2017, 8) described teaching as 'a profession of career-long learners working together'.

The future is increasingly part of teachers' work. According to Cheng (2012), a new wave of educational reforms in the twenty-first century has emphasised making education relevant to the future development of individuals and society. Lee and Tan 
(2018) summarised the core competences generally considered important for twentyfirst-century citizens. These competences include creativity, innovation, critical thinking, problem-solving capabilities, communication skills, collaboration, information and digital literacy, conflict resolution, and social and inter-cultural skills. These kinds of competences are more generic than typical subject matter-based objectives and thus require teachers to master new kinds of skills (see, e.g., Saavedra and Opfer 2012). Schleicher (2012) argued that the learning of routine cognitive skills is no longer relevant because these skills are easy to digitise, automate, and outsource. Instead, teaching more complex knowledge and skills that support students' deep understanding is essential. Teachers play an important role in students' lives and futures. According to Darling-Hammond (2010) and Wei et al. (2009), to best support students' learning processes, teachers' professional development should be organised in such a way that it may enhance twenty-first-century learning and strong professional practice.

\section{Newly qualified teachers at the beginning of career-long development}

Newly qualified teachers (NQTs) immediately face numerous professional demands upon starting work. Several studies have addressed the significance of the first working years (e.g., Engvik and Emstad 2017; Kearney 2015; Voss et al. 2017), known as the induction phase (Geeraerts et al. 2015). While this period is vital for teachers' lifelong professional development (Geeraerts et al. 2015), it can also cause emotional exhaustion (Voss et al. 2017), partly because teacher-education programmes cannot fully prepare NQTs for the realities of the profession (Heikkinen, Jokinen, and Tynjälä 2008). According to Fransson and Gustafsson (2008), this failure results from the everchanging character of teachers' work as well as the very nature of knowledge, skills, and competence, all of which require time and experience to develop. 
The induction phase has become an important topic both in Europe and globally. Teachers' professional development is often seen as a continuous process containing the phases of initial teacher education, induction, and continuing professional lifelong learning (see, e.g., European Commission 2010). Although teachers need support in every phase of their careers, support is especially essential during the first years, which largely form the base that teachership is built upon. NQTs often find the induction phase demanding, as it requires constant learning and familiarisation with pedagogical environments and school communities, their culture and policies, and context-specific conditions (Fransson and Gustafsson 2008; Kane and Francis 2013). In order to best support NQTs during this sensitive career time, it is essential to identify the work tasks and professional competences that most tax beginning teachers (Conway et al. 2009).

Several earlier studies have investigated the support needs of NQTs. These studies have often investigated teachers' needs from the viewpoints of the NQTs themselves (e.g., Harju and Niemi 2016; Menon 2012; Schuck et al. 2018), but they have also approached the topic from the perspectives of other members of school communities, such as school leaders (e.g., Chong et al. 2012; Grimsæth, Nordvik, and Bergsvik 2008; Sunde and Ulvik 2014). Although researchers often consider the induction phase to be vital to teachers' professional development, knowledge about NQTs' needs today - when the profession faces increasing demands - is lacking.

Previous researchers have found that NQTs face several challenges related to the themes of teaching and pedagogy. These challenges might include managing classroom interactions, familiarising oneself with the curriculum and the students (Kane and Francis 2013), differentiating teaching (Harju and Niemi 2016), and assessing and providing feedback (Chong et al. 2012). In addition, studies have found that NQTs' support needs are connected to cooperating with parents or getting to know the school 
organisation and its culture (see, e.g., Gaikhorst et al. 2017; Grimsæth, Nordvik, and Bergsvik 2008; Kane and Francis 2013). Harju and Niemi (2016) have also reported on the support required to develop teaching and other activities in schools as well as to facilitate cooperation with community members both inside and outside the school. Grimsæth, Nordvik, and Bergsvik (2008) have emphasised the importance of developing independence. In the study of Harju and Niemi (2016), NQTs from four European countries perceived the need for more support for acting in conflict situations in schools, for example when bullying occurs.

While many researchers have noted a lack of understanding about NQTs' support needs, Kane and Francis (2013) asserted that the challenges NQTs face have remained quite stable, which could partly stem from the specific features of the initial career stage (see, e.g., Feiman-Nemser 2001) but also because studies are often conducted from the classroom perspective. In the present study, we wish to examine NQTs' needs when performing professional roles that extend beyond classroom teaching.

Many European countries aim to organise the induction as well as connect it with pre-service teacher education (see, e.g., Eisenschmidt 2006; Harford and O'Doherty 2016; Livingston 2012). However, many tensions exist on how different teacher education phases can be linked with each other at the policy level and in practice. We need more knowledge about how the induction could be organised and which themes of support are urgent for NQTs. This study focuses on the contents of the induction and what school leaders consider to be most essential for inclusion. However, the study also provides important knowledge in relation to what should be strengthened within pre-service programmes. 


\section{School leaders as key actors in providing support to NQTs}

School Leaders (SLs) are responsible for ensuring that schools work effectively. They may have different roles in centralised and de-centralised education systems, and their roles may range from managers to pedagogical leaders. In all their roles, however, they can perceive how well teachers are working and if they require any support. One important task in SLs' work is to create learning communities; as such, the present study seeks to determine SLs' perceptions about NQTs' needs and professional competences.

Numerous studies have highlighted the role of SLs in supporting NQTs during their early careers and in creating positive teaching and learning environments (see, e.g., Aspfors and Bondas 2013; Cheng and Szeto 2016; Engvik and Emstad 2017; NasserAbu Alhija and Fresko 2010). The European Commission (2010) divided the support NQTs receive into professional, social, and personal dimensions. According to Eisenschmidt (2006), the processes of support take place simultaneously within all three dimensions. According to the European Commission (2010), the professional dimension includes teacher competences of pedagogical knowledge and skills, while the social dimension relates to the processes of becoming a member of the school community and of understanding and accepting the community's qualities, norms, and manners; this dimension also includes wider socialisation within the professional community. The personal dimension refers to the processes of developing a professional teacher identity as well as the emotions and perceptions of teachers' self-efficacy and self-esteem. In addition, the personal dimension involves 'the elaboration of personal norms towards pupils and colleagues, the elaboration of the teacher's view on teaching and learning [...] and the development of an attitude of lifelong learning' (European Commission 2010, 15). 
Although SLs primarily organise support rather than serve as mentors themselves, we assume in this study that their perceptions about NQTs' needs are important in creating relevant support systems.

\section{Research question and methodology}

\section{Research question}

This study examines how SLs and NQTs perceive the wide-ranging demands of the teaching profession and NQTs' professional growth. The study also investigates the similarities and differences in these perceptions. The research question is: How do SLs and NQTs perceive the support needs of NQTs in the wide-ranging and demanding profession of teaching?

\section{The Finnish context}

In Finland, all primary and secondary school teacher qualifications require a master's degree (i.e., a five-year university programme). In Finland's decentralised education and curriculum system, SLs and teachers are responsible for local curricula. Teachers have considerable professional autonomy and can choose teaching and assessment methods as well as learning materials. Teaching happens in mixed-ability groups. SLs and teachers are responsible for the quality of learning outcomes and students' wellbeing.

Finnish pre-service teacher education has been widely praised as providing high standards of professional competences (Darling-Hammond and Lieberman 2012). However, the complexity of schools and the evolving profession have created a need for support of NQTs, who are expected to take on all the responsibilities of the wider professional role. Finland lacks a formal nationwide induction system. Instead, 
individual schools are responsible for organising mentoring activities, and much variation exists among schools. Ongoing efforts are underway at the national level to develop programmes for teachers' pre-service, induction, and in-service education (see, e.g., Finland Ministry of Education and Culture 2016). In this study, we assume that the Finnish case can provide new knowledge for other countries where support systems will be developed for NQTs.

\section{Participants and data gathering}

The study was part of the EU-funded Erasmus+ Key Action 2 project called the Outstanding Newly Qualified Teacher Program (www.ontp.org). Data were collected through the dissemination of an e-questionnaire to Finnish NQTs in autumn 2015 and spring 2016 and to SLs during the autumn of 2016.

The Trade Union of Education and 200 SLs throughout Finland were asked to forward the questionnaire to potential NQTs. In total, 145 NQTs responded. SL participants were contacted through the Finnish principals' association, as well as through personal emails sent to 250 SLs working in comprehensive and general upper secondary schools. In all, 104 SL responses were analysed.

\section{Instrument and analyses}

The questionnaires for both SLs and NQTs consisted of 40 professional competences (see Table 2) covering a wide spectrum of teachers' professional work, including pedagogical skills, the support of students' holistic development, the ability to work in school communities and with external stakeholders, and teacher responsibilities for their own career-long learning. The instrument was used and validated in several earlier studies (e.g., Harju and Niemi 2016; Niemi 2012; Niemi and Nevgi 2014; Niemi, Nevgi, and Aksit 2016). 
SLs were asked to identify aspects where NQTs required support, whereas NQTs were asked to evaluate their own support needs. The participants responded on a 5-point Likert scale: (1) not at all or very little, (2) a little, (3) somewhat, (4) much, and (5) very much. The questionnaires for SLs and NQTs also included open-ended questions. SLs were asked to describe the competences they thought NQTs would especially need more support on, while NQTs were asked to describe their own experiences of earlier teacher training and what kinds of support they would like to have for their own professional development.

The quantitative data were analysed using various descriptive statistics, including means, standard deviations, and statistical differences between SLs and NQTs. The qualitative data were analysed using inductive qualitative content analysis. The length of responses varied from several sentences to short, one-sentence descriptions. In all, 50 pages of text were included in the analysis. The data were read through several times. Thematic analysis was used to form the categories - that is, the themes of professional competences - as a dialogue between the data and earlier research (see, e.g., Hyytinen et al. 2014).

\section{Results}

SLs and NQTs emphasised several of the same professional competences as those in which NQTs required support. In particular, six of the ten most-emphasised needs were the same between both groups. These competences included acting in conflict situations, differentiating teaching, developing the school curriculum, evaluating and grading students, evaluating students' learning capacities, and working with studentwelfare groups (Table 1).

[Table 1 near here] 
As the table shows, both groups considered the most urgent needs to be related to students' learning and life. The most common issue was managing conflict situations, such as bullying at schools. While classroom pedagogy was not on the list, the participants emphasised differentiation, assessments, and students' well-being. Both groups also mentioned curriculum development. These perceptions all indicate that NQTs have demanding tasks and need support. One interesting difference between the identified needs was that SLs evaluated cooperation with parents as their fourth priority, whereas NQTs did not identify this aspect as being among their most urgent support needs.

Independent-sample $t$-tests were executed to examine possible statistical differences between the means of SLs and NQTs (Table 2).

[Table 2 near here]

Significant differences in the perceptions of SLs and NQTs were indicated in thirteen variables. Among these variables, SLs' means were generally higher than NQTs' assessments. Some competences were present in both top 10 lists, but SLs identified several other support needs as being more important than NQTs did. The thirteen competences were as follows: managing classroom interactions, managing tasks outside the classroom, working in school communities with teachers and other school staff, working with student-welfare groups, developing one's own educational philosophy, preparing students for daily life, cooperating with parents, independently managing teacher tasks, becoming aware of the ethical basis of the teaching profession, committing to the teaching profession, pursuing lifelong professional growth, researching one's own work, and critically reflecting on one's own work.

One interesting result is that SLs emphasised NQTs' needs as covering a wide professional role related to student learning, NQTs' own growth process, and the ethical 
basis of the profession. SLs also saw managing tasks outside the classroom, working in school communities with teachers and other school staff, and cooperating with parents as important areas of support.

Qualitative descriptions of both groups were categorised under six partly overlapping themes (see Table 3), which deepened the quantitative results. Next, these descriptions are discussed in more detail.

[Table 3 near here]

\section{Teaching and pedagogy}

Although professional competences related to teaching and pedagogy were not particularly emphasised in the quantitative evaluations, SLs and NQTs alike described these themes in their open-ended responses. For example, both groups described managing classroom interactions, implementing curricula, acquiring knowledge of new and versatile teaching/working methods, and learning how to evaluate students' learning as essential support needs. Some teachers also mentioned a need for more support in designing teaching and in acquiring subject-specific knowledge. One NQT described the uncertainly related to teaching and evaluating as follows.

Even after three working years, I'm still uncertain about how much time to use in certain themes and how I should teach certain topics [...] Evaluation is also still a challenge. For example, I'm often unsure how to assess essays, and it takes me an incredibly long time to decide on the grades.

SLs and NQTs also emphasised that it was essential for NQTs to have support when acting in and developing new learning environments. According to one SL, the support required for this area was relevant for NQTs and other personnel alike: 'Both new and more experienced teachers need support in introducing new teaching methods and a 
new curriculum'. Some teachers also noted a need for support in learning to carry out multidisciplinary teaching and to use new digital technologies in the current situation, where learning materials and evaluation systems are becoming increasingly digitalised. One NQT wrote:

For example, the national matriculation examinations [that students take at the end of upper secondary school] will be done in a digital environment, but in my school, we haven't practiced using any math software or used the Abitti environment [a course exam system of the national Matriculation Examination Board].

\section{Supporting students' comprehensive individual growth}

The study participants described the professional competences related to this theme from several perspectives. Both SLs and NQTs stated that support for fostering students' comprehensive growth rather than their academic skills was essential. They also perceived a need for support in acquiring competences in enhancing students' socio-emotional skills and well-being.

Some SLs and NQTs wrote that NQTs needed support to focus on students' learning instead of their own teaching. One teacher asked, 'How can I get rid of teachercentred teaching?' Both groups considered paying attention to students' individual needs and differentiating teaching as essential areas of support for NQTs. As one NQT wrote, 'Differentiating teaching is still a challenge in classes where both highly gifted and weak students should be taken into account'.

Both SLs and NQTs also emphasised that it was essential to get support in acquiring knowledge about special education and skills and in applying that knowledge to their own work. One teacher wrote, 'The growing number of special education students requires new ways of teaching, too. This is a topic in which tools [e.g., new teaching and assessment methods] are really needed!' Respondents also wrote that 
NQTs needed more support in conforming with Finland's Pupil and Student Welfare Act and student-welfare services together in cooperation with different authorities.

One essential competence that only NQTs mentioned was multicultural competence. Study participants mentioned this factor in several descriptions, although they did not evaluate it as being very important in their quantitative survey responses. One NQT wrote, 'I'd like to have more Finnish-as-a-second-language studies [in teacher education] [...] Today, many schools have immigrants, which should be taken into account in teacher education'.

New teachers also wished to have more support in acquiring knowledge about different cultures, religions, and customs in order to better support individual students and to collaborate with their families. One NQT wrote:

I don't consider students' different cultural backgrounds as a problem or something that we should make a big deal about. We're all human beings. Knowledge about a variety of cultures and related habits would be beneficial. Such training should happen in teacher education.

Another teacher felt that she already knew how to take diversity and multiculturalism into account in her teaching, but she felt that more support was needed to discuss these themes with students: 'I can handle diversity and multiculturalism very well, but I would like to encourage the students to [learn about] other people's differences and multiculturalism. I often hear pretty intense comments [from the students]'.

\section{Professional identity and growth}

The SLs' and NQTs' responses also addressed professional growth. SLs in particular discussed this theme from the viewpoint of developing a professional identity. Some wrote that NQTs needed support in finding and forming their teacher identity and in reflecting the value base and the concepts of education and learning. Several NQTs felt 
that having possibilities for discussions would support them in their professional growth; some also emphasised the importance of independence and pursuing their own activities. In the following quote, one NQT discussed the topic from both perspectives:

Peer-group mentoring [...] would help in considering ethical issues and structuring our own concepts of education [...] Having our own active thinking, knowledge acquisition, and self-development would help to shape my own philosophy/concepts [related to education and learning].

Some NQTs perceived a need for support in finding motivation and time for consciously reflecting on and developing their own work. Because the first years in the teaching profession are full of new experiences and contain much to learn, teachers may have little time to consciously develop themselves. One teacher wondered, 'How will I occasionally remember/have time/manage to stop and reflect on my own work from a wider perspective?' Another teacher continued this thought:

I feel like I'll only be able to manage to develop as a teacher once I get a permanent job. Now there's always a new school, students, and practices [...] The situation is frustrating and decreases my motivation because I feel that I can never be as good a teacher as I could be.

Several NQTs also asked for additional training to develop their professional competences. One of them stated that "continuous training should be provided on topical issues and themes that should be developed in schools and implemented in teaching'. The SLs' comments voiced emotional support and an acceptance of NQTs' growth. SLs acknowledged that pressures can come as a surprise and that 'everything does not always succeed. [Support is important so that new teachers do] not become immediately exhausted by different pressures and requirements. They have to learn to be kind to themselves-everything in every class does not always succeed.' SLs felt 
that it was essential that NQTs learn to accept their own professional incompleteness and give themselves time to grow.

\section{Independent working}

In addition, the participants emphasised support to encourage independent work in their open-ended responses; several SLs in particular perceived this as an important support need. They felt that NQTs needed to learn how to act in complex and often unexpected situations as well as to be flexible and adaptable. As one SL described:

\footnotetext{
Working days are hectic, and a teacher should know how to rapidly change plans. Lessons and work days don't often appear as planned from the previous evening. In the beginning, a teacher needs support in coordinating the pedagogical aims and surprising variables.
}

Some SLs also mentioned requirements for accountability and responsibility in their responses. One wrote that support was needed 'in being an adult and taking responsibility during complex and perhaps surprising everyday situations at school'.

In addition, independent working was connected with the requirements of finding one's own style of teaching. For example, one SL wrote that it was important to develop one's own ways of doing things instead of acquiescing to existing methods. This SL specified that 'teachers must also maintain their own autonomy and find their own style [of teaching], not just adopt mentor-provided guidance and ready-made methods'.

Both SLs and NQTs saw that it was essential for NQTs to learn how to set boundaries for their own work. One NQT wrote, 'The biggest development point for me is how to limit work and how to compress planning [time]. I've spent lots of time designing basic things'. Teachers also wrote about pressures and feelings of uncertainty, inadequacy, and incompetence that were present at the beginning of their careers. SLs 
also noted these factors and expressed that NQTs can easily become distressed by their workloads. In addition to learning to accept one's own professional incompleteness, one SL responded that teachers needed support in learning 'how to be kind to themselves. Everything can't always be achieved, and [NQTs] must be able to make choices about what and how to teach different content'. Overall, SLs emphasised support to act independently in complex, challenging, and unexpected situations because 'situations are so complicated and students so dissimilar that the same rules cannot be applied in the same way everywhere.'

\section{Work in school communities}

Some SLs perceived that NQTs needed support in understanding the extent of the teaching profession. One SL wrote, 'New teachers need support in mastering the profession as a whole. It may come as a surprise for many people that [teaching] is more than just preparing and carrying out lessons'. New teachers also wished to gain more support in confronting the everyday aspects of the profession: for example, how to act as a tutor, carry out disciplinary educational discussions, and supervise recesses and exams.

Some SLs and teachers also emphasised the need to become familiar with certain aspects of school culture. One SL described the support needs of NQTs as 'commitment to the goals of the school and to understand the common rules, which are often implicit'. In line with this identified need, new teachers wished to obtain more support in discussing ethical issues and in understanding the legislation/rules related to professional confidentiality; for example, some wondered when and with whom information about students should be shared.

Study participants also mentioned a need for interaction and collaboration among colleagues as well as for support in undertaking collaborative work in schools. 
This support could include pedagogical work. One NQT wrote, 'During our pedagogical studies, cross-curricular collaboration [between teachers] barely took place. Today, in our working lives, people increasingly execute such collaborations'. Some NQTs expressed a need for support in understanding the work tasks and division of assignments related to collaboration in school communities. For example, one stated:

Today, much cooperation happens with various parties. I must admit that I don't really know the extent to which all the meetings and things are part of my job. I'm gladly involved in most of the working groups, but they take up a lot of time. When can I say no? What are the limits and rules? I can manage 'my own pedagogical work', although that kind of separation is out of date, but I don't know how much more I should still do in addition to that.

Although most participants viewed getting familiar with certain aspects of school culture as important, they also related essential professional competence to renewing and developing the objectives and practices of the school community. This aspect was especially important to SLs, who noted that NQTs needed support in developing local curricula and the ways of working in school communities. One SL stated that NQTs 'need support so that they can really renew and change practices at school. A working community that's worked together for a long time may sometimes frustrate an eager new person'.

\section{Collaboration with out-of-school partners}

According to the participants responses, central collaboration partners outside the school include professionals on student multi-professional teams (e.g., school psychologists and school social workers), parents or legal guardians, and community members such as social-services authorities or working life representatives. Both SLs and NQTs mentioned that support was needed in collaborating with these partners, 
especially when dealing with problematic and difficult situations. One NQT wrote, 'We had hardly any training about meeting parents - especially those who are challenging. We need practical support for awkward situations in schools'.

\section{Discussion and conclusions}

The professional competences that SLs perceived as the most urgent needs of NQTs largely corresponded with those identified by the NQTs themselves. Most needs focused on students' learning and diversity, differentiating teaching, acquiring competence for special needs education, and working with student-welfare groups. These findings were evident both in the quantitative and the qualitative data and have been indicated by earlier research in other countries (see, e.g., Mohamed, Valcke, and De Wever 2017). We can confirm Alexiadou's and Essex's (2016) notion that, in a world of growing diversity in social, economic, and cultural backgrounds, teachers need competences to encounter every student individually and to support that student's learning comprehensively. Surprisingly, the management of conflict situations in schools was among the highest priorities in both groups. Schools are complex environments, and teachers' work has expanded beyond simply being classroom teachers (see, e.g., OECD 2017a, 2017 b). One indication of schools' complexity was the NQTs' request for support in building multicultural competence. Teachers need more knowledge about different cultures, religions, and customs and skills in taking diversity and multiculturalism into account in their teaching. Recent studies have reported similar findings (see, e.g., Gaikhorst et al. 2017).

The OECD (2017a, 2017b) has painted a picture of future schools as innovative learning environments. Instead of just reacting to changes in the outside world (e.g., technological advances or increased diversity), schools should be perceived as part of the network actively taking part in changing circumstances. In this study, both SLs and 
NQTs emphasised support for teachers' creative, collaborative work, particularly for designing both curricula and new learning environments.

As teachers' roles expand (e.g., Toom and Husu 2018), many new demands for their own learning emerge. For example, Balyer, Karataş, and Alci (2015) emphasised the importance of a collaborative working culture and described today's schools as professional learning communities (see also Caena 2014; OECD 2017a, 2017b). This aspect was evident in both the SLs' and the NQTs' assessments. The results of this study suggest that NQTs need professional competences for working with colleagues and other school community members. SLs emphasised even more than NQTs the importance of these collaborative competences within a school community and when working with parents.

The qualitative data also revealed the need for pedagogical support, however, which may stem from changes in curriculum and educational policy, that also place new demands on pedagogy and new learning environments (see e.g. Guerriero 2017).

The European Commission/EACEA/Eurydice (2018) has pointed out the importance of adapting to new challenges in the teaching environment. In order for teachers to adapt to their environment, lifelong professional development and wellstructured support systems for teachers are needed (see also, e.g., Bressman, Winter, and Efron 2018; Livingstone 2012). As this study indicates, teachers' growth relies on both their independent activity and the resources offered by others.

The study provides new knowledge by identifying the support needs of NQTs. The main message is that teachers' work has widened to include the whole school community. With partners outside the school, teachers work with diverse student groups and provide holistic support for different learners (see, e.g., Guerriero 2017; OECD 2017a, 2017b). As they grow as professionals, NQTs need support that will help them in 
taking on all the responsibilities that are now included in their new and very broad professional roles.

The variety and complexity of the professional competences and support needs set challenges for both pre-service teacher education and induction (see, e.g., BenPeretz and Flores 2018, Gudmundsdottir and Hatlevik 2018, Livingston 2012). Preservice programmes should already be aware of the widening role of teachers. This study highlights the need for both pre-service and induction phases to support teachers' professional development to make schools real learning communities for students and teachers. The complex environment requires more collaboration and interaction between teacher education and schools. Similarly, Postholm (2016) highlighted the importance of collaboration between teacher educators, SLs, and teachers in supporting the professional development of teachers.

Earlier research has examined ways to support teaching and learning of complex professional competences in pre-service teacher education. For example, Tynjälä et al. (2016) investigated student-teachers' learning experiences by focusing on the development of social competence and other generic skills. They found that pedagogical methods that included discussions, sharing experiences, and collaboration with a strong emphasis on integration of theory and practice (see also, e.g., Tang, Wong, and Cheng 2016) were effective for teachers' future work. However, further research is still needed to investigate when and how complex professional competences should be taught and learned in order to best support students, student-teachers, and NQTs.

\section{Limitations}

This study's quantitative analysis was based primarily on average levels, and different participants' responses may vary considerably. Because the study included relatively few respondents, we have used its findings to describe the topic as a case instead of 
trying to form a representative picture of the situation in Finland. Also, the equestionnaire forced respondents to choose between set options, which may have led some respondents to choose options that did not fully correspond to their experience. However, the open-ended questions gave respondents the chance to discuss and reflect on their opinions more freely.

\section{Ethical statement}

The researchers have no conflict of interest and conducted the study based on the research guidelines of the Finnish Advisory Board on Research Integrity (2009) and the European Code of Conduct for Research Integrity (2017). In addition, the researchers have followed the open-data policy of the University of Helsinki (2015).

\section{References}

Alexiadou, Nafsika, and Jane Essex. 2016. "Teacher Education for Inclusive Practice Responding to Policy." European Journal of Teacher Education 39 (1): 5-9. doi:10.1080/02619768.2015.1031338.

Aspfors, Jessica, and Terese Bondas. 2013. "Caring about Caring: Newly Qualified Teachers' Experiences of Their Relationships within the School Community." Teachers and Teaching 19 (3): 243-259. doi:10.1080/13540602.2012.754158.

Balyer, Aydin, Hakan Karataş, and Bülent Alci. 2015. "School Principals' Roles in Establishing Collaborative Professional Learning Communities at Schools." Procedia - Social and Behavioral Sciences 197: 1340-1347. https://doi.org/10.1016/j.sbspro.2015.07.387.

Ben-Peretz, Miriam and Flores, Maria Assunção. 2018. "Tensions and Paradoxes in Teaching: Implications for Teacher Education." European Journal of Teacher Education 41 (2): 202-213. doi:10.1080/02619768.2018.1431216.

Bressman, Sherri, Jeffrey S. Winter, and Sara Efrat Efron. 2018. "Next Generation Mentoring: Supporting Teachers Beyond Induction." Teaching and Teacher Education 73: 162-170. https://doi.org/10.1016/j.tate.2018.04.003. 
de Brü̈ne, Erica J., T. Martijn Willemse, Jeanne D’Haem, Peter Griswold, Lijne Vloeberghs, and Sofie van Eynde. 2014. "Preparing Teacher Candidates for Family-School Partnerships.” European Journal of Teacher Education 37 (4): 409-425. doi:10.1080/02619768.2014.912628.

Caena, Francesca. 2014. "Teacher Competence Frameworks in Europe: Policy-asDiscourse and Policy-as-Practice.” European Journal of Education 49 (3): 311331. https://onlinelibrary.wiley.com/doi/abs/10.1111/ejed.12088.

Cheng, Annie Y. N., and Elson Szeto. 2016. "Teacher Leadership Development and Principal Facilitation: Novice Teachers' Perspectives." Teaching and Teacher Education 58: 140-148. http://dx.doi.org/10.1016/j.tate.2016.05.003.

Cheng, Yin-Cheong. 2012. "Teachers for New Learning: Reform and Paradigm Shift for the Future." In Teacher Education Frontiers: International Perspectives on Policy and Practice for Building New Teacher Competences, edited by O.-S. Tan, 93-121. Singapore: Cengage Learning.

Chong, Sylvia, Jerome Rotgans, Wai Mun Loh, and Mabelene Mak. 2012. "Modelling the Determinants of School Leaders' Perceptions of Beginning Teachers' Efficacy." Educational Research and Evaluation 18 (3): 231-244.

Clandinin, D. Jean, C. Aiden Downey, and Janice Huber. 2009. “Attending to Changing Landscapes: Shaping the Interwoven Identities of Teachers and Teacher Educators.” Asia-Pacific Journal of Teacher Education 37 (2): 141-154. doi:10.1080/13598660902806316.

Conway, Paul F., Rosaleen Murphy, Anne Rath, and Kathy Hall. 2009. Learning to Teach and Its Implications for the Continuum of Teacher Education: A NineCountry Cross-National Study. Ireland: Teaching Council.

Darling-Hammond, Linda. 2010. The Flat World and Education: How America's Commitment to Equity Will Determine Our Future. New York: Teachers College Press.

Darling-Hammond, Linda, and Ann Lieberman, eds. 2012. Teacher Education around the World. Changing Policies and Practices. New York: Routledge.

Eisenschmidt, Eve. 2006. "Implementation of Induction Year for Novice Teachers in Estonia. Abstract.” Dissertations on Social Sciences. No. 25. Tallinn: Tallinn University Press. https://www.ht.ut.ee/sites/default/files/ht/e_eisenschmidt_vaitekiri.pdf. 
Engvik, Gunnar, and Anne Berit Emstad. 2017. "The Importance of School Leaders'

Engagement in Socialising Newly Qualified Teachers into the Teaching

Profession.” International Journal of Leadership in Education 20 (4): 468-490.

European Code of Conduct for Research Integrity. 2017. Revised edition. Berlin:

ALLEA - All European Academies.

https://ec.europa.eu/research/participants/data/ref/h2020/other/hi/h2020-

ethics_code-of-conduct_en.pdf.

European Commission. 2010. "Developing Coherent and System-Wide Induction

Programmes for Beginning Teachers: A Handbook for Policymakers." Brussels. http://ec.europa.eu/education/policy/school/doc/handbook0410_en.pdf.

European Commission. 2017. "Communication from the Commission to the European

Parliament, the Council, the European Economic and Social Committee and the

Committee of the Regions. School Development and Excellent Teaching for a

Great Start in Life."

https://ec.europa.eu/education/sites/education/files/school-com-2017-

248_en.pdf.

European Commission/EACEA/Eurydice. 2018. "Teaching Careers in Europe: Access,

Progression and Support.” Eurydice Report. Luxembourg: Publications Office of

the European Union. https://publications.europa.eu/en/publication-detail/-

/publication/435e941e-1c3b-11e8-ac73-01aa75ed71a1/language-en.

European Union. 2014. "Council Conclusions of 20 May 2014 on Effective Teacher

Education." Official Journal of the European Union C 183: 22-24. https://eur-

lex.europa.eu/legal-

content/EN/TXT/PDF/?uri=CELEX:52014XG0614(05)\&from=EN.

Feiman-Nemser, Sharon. 2001. "From Preparation to Practice: Designing a Continuum

to Strengthen and Sustain Teaching." Teachers College Record 103 (6): 1013-

1055. http://www.geocities.ws/cne_magisterio/4/curricfomdocente.pdf.

Finland Ministry of Education and Culture. 2016. A New Teacher Education

Development Programme Launched: Teachers' Competence Must Be Developed Methodically throughout Their Careers. Press release 13 October 2016. Finland. http://minedu.fi/artikkeli/-/asset_publisher/opettajankoulutuksen-

kehittamisohjelma-julkistettiin-opettajien-osaamista-kehitettava-

suunnitelmallisesti-lapi-

tyouran?_101_INSTANCE_0R8wCyp3oebu_languageId=en_US. 
Finnish Advisory Board on Research Integrity. 2009. Humanistisen,

yhteiskuntatieteellisen ja käyttäytymistieteellisen tutkimuksen eettiset periaatteet ja ehdotus eettisen ennakkoarvioinnin järjestämiseksi [Ethical Principles of

Research in the Humanities and Social and Behavioural Sciences and a Proposal for an Ethical Ex-ante Evaluation]. Helsinki: Tutkimuseettinen neuvottelukunta. http://www.tenk.fi/sites/tenk.fi/files/eettisetperiaatteet.pdf.

Fransson, Göran, and Christina Gustafsson. 2008. "Becoming a Teacher: An Introduction to the Theme and the Book." In Newly Qualified Teachers in Northern Europe: Comparative Perspectives on Promoting Professional Development, edited by G. Fransson and C. Gustafsson, 11-26. Gävle, Sweden: University of Gävle.

Gaikhorst, Lisa, Jos Beishuizen, Bart Roosenboom, and Monique Volman. 2017. "The Challenges of Beginning Teachers in Urban Primary Schools.” European Journal of Teacher Education 40 (1): 46-61. http://dx.doi.org/10.1080/02619768.2016.1251900.

Gartmeier, Martin, Markus Gebhardt, and Benjamin Dotger. 2016. "How Do Teachers Evaluate Their Parent Communication Competence? Latent Profiles and Relationships to Workplace Behaviors." Teaching and Teacher Education 55: 207-216. https://doi.org/10.1016/j.tate.2016.01.009.

Geeraerts, Kendra, Päivi Tynjälä, Hannu L. T. Heikkinen, Ilona Markkanen, Matti Pennanen, and David Gijbels. 2015. "Peer-Group Mentoring as a Tool for Teacher Development." European Journal of Teacher Education 38 (3): 358377. doi:10.1080/02619768.2014.983068.

Grimsæth, Gerd, Grete Nordvik, and Eli Bergsvik. 2008. “The Newly Qualified Teacher: A Leader and a Professional? A Norwegian Study.” Journal of InService Education 34 (2): 219-236. doi:10.1080/13674580801950873.

Gudmundsdottir, Greta Björk, and Ove Edvard Hatlevik. 2018. "Newly Qualified Teachers' Professional Digital Competence: Implications for Teacher Education.” European Journal of Teacher Education 41 (2): 214-231. doi:10.1080/02619768.2017.1416085.

Guerriero, Sonia, ed. 2017. Pedagogical Knowledge and the Changing Nature of the Teaching Profession. Paris: OECD Publishing. http://dx.doi.org/10.1787/9789264270695-en. 
Harford, Judith, and Teresa O'Doherty. 2016. "The Discourse of Partnership and the Reality of Reform: Interrogating the Recent Reform Agenda at Initial Teacher Education and Induction Levels in Ireland." CEPS Journal: Center for Educational Policy Studies Journal 3: 37-58.

Harju, Vilhelmiina, and Hannele Niemi. 2016. "Newly Qualified Teachers' Needs of

Support for Professional Competences in Four European Countries: Finland, the United Kingdom, Portugal, and Belgium." CEPS Journal 6 (3): 77-100.

Heikkinen, Hannu, Hannu Jokinen, and Päivi Tynjälä. 2008. "Reconceptualising Mentoring as a Dialogue." In Newly Qualified Teachers in Northern Europe: Comparative Perspectives on Promoting Professional Development, edited by G. Fransson and C. Gustafsson, 107-124. Gävle, Sweden: Gävle University Press.

Hyytinen, Heidi, Katariina Holma, Auli Toom, Richard J. Shavelson, and Sari Lindblom-Ylänne. 2014. 'The Complex Relationship between Students' Critical Thinking and Epistemological Beliefs in the Context of Problem Solving." Frontline Learning Research 2 (5): 1-25. http://dx.doi.org/10.14786/flr.v2i4.124.

Kane, Ruth G., and Andrew Francis. 2013. "Preparing Teachers for Professional Learning: Is There a Future for Teacher Education in New Teacher Induction?" Teacher Development 17 (3): 362-379. doi:10.1080/13664530.2013.813763. Kearney, Sean. 2015. "Reconceptualizing Beginning Teacher Induction as Organizational Socialization: A Situated Learning Model.” Cogent Education 2 (1). https://doi.org/10.1080/2331186X.2015.1028713.

Lee, Wing On, and Jennifer Pei-Ling Tan. 2018. "The New Roles for Twenty-First-

Century Teachers: Facilitator, Knowledge Broker, and Pedagogical Weaver.” In The Teacher's Role in the Changing Globalizing World: Resources and Challenges Related to the Professional Work of Teaching, edited by H. Niemi,

A. Toom, A. Kallioniemi, and J. Lavonen, 11-31. Leiden: Brill Sense.

Livingston, Kay. 2012. Quality in Teachers' Professional Career-Long Development. In Quality Assurance and Teacher Education: International Challenges and Expectations, edited by J. Harford, B. Hudson, and H. Niemi, 35-51. Bern: Peter Lang.

Lonka, Kirsti, Lauri Hietajärvi, Mona Moisala, Heta Tuominen-Soini, Lauri Vaara, Kai Hakkarainen, and Kristiina Salmela-Aro. 2015. "Working Document I.” In 
Innovative Schools: Teaching \& Learning in the Digital Era - Workshop

Documentation, edited by the European Parliament, 5-46. Brussels: European

Parliament.

http://www.europarl.europa.eu/RegData/etudes/STUD/2015/563389/IPOL_STU (2015)563389_EN.pdf.

Menon, Maria Eliophotou. 2012. "Do Beginning Teachers Receive Adequate Support from Their Headteachers?" Educational Management Administration \& Leadership 40 (2): 217-231. doi:10.1177/1741143211427981.

Mohamed, Zulaikha, Martin Valcke, and Bram De Wever. 2017. "Are They Ready to Teach? Student Teachers' Readiness for the Job with Reference to Teacher Competence Frameworks." Journal of Education for Teaching 43 (2): 151-170. doi:10.1080/02607476.2016.1257509.

Nasser-Abu Alhija, Fadia, and Barbara Fresko. 2010. "Socialization of New Teachers: Does Induction Matter?" Teaching and Teacher Education 26 (8): 1592-1597. doi:10.1016/j.tate.2010.06.010.

Niemi, Hannele. 2012. “Teacher Education for High Quality Professionals: An Analysis from the Finnish Perspectives.” In Teacher Education Frontiers: International Perspectives on Policy and Practice for Building New Teacher Competencies, edited by O. S. Tan, 43-69. Singapore: Cengage Learning Asia Pte Ltd.

Niemi, Hannele, and Anne, Nevgi. 2014. "Research Studies and Active Learning Promoting Professional Competences in Finnish Teacher Education.” Teaching and Teacher Education. 43: 131-142.

Niemi, Hannele, Anne Nevgi, and Fisun Aksit. 2016. “Active Learning Promoting Student Teachers' Professional Competences in Finland and Turkey." European Journal of Teacher Education 39 (4): 471-490.

OECD. 2017a. The OECD Handbook for Innovative Learning Environments. Paris: OECD Publishing. http://dx.doi.org/9789264277274-en.

OECD. 2017b. Schools at the Crossroads of Innovation in Cities and Regions. Paris: OECD Publishing. http://dx.doi.org/10.1787/9789264282766-en.

Postholm, May Britt. 2016. "Collaboration between Teacher Educators and Schools to Enhance Development.” European Journal of Teacher Education 39 (4): 452470. doi:10.1080/02619768.2016.1225717. 
Saavedra, Anna Rosefsky, and V. Darleen Opfer. 2012. "Learning 21st-Century Skills Requires 21st-Century Teaching.” Phi Delta Kappan 94 (2): 8-13. http://journals.sagepub.com/doi/pdf/10.1177/003172171209400203.

Schleicher, Andreas. 2012. "The Case for 21 st Century Teacher Policies.” In Teacher Education Frontiers: International Perspectives on Policy and Practice for Building New Teacher Competences, edited by O.-S. Tan, 21-41. Singapore: Cengage Learning.

Schuck, Sandy, Peter Aubusson, John Buchanan, Meera Varadharajan, and Paul F. Burke. 2018. "The Experiences of Early Career Teachers: New Initiatives and Old Problems." Professional Development in Education 44(2): 209-221. https://doi.org/10.1080/19415257.2016.1274268

Sunde, Eva, and Marit Ulvik. 2014. “School Leaders' Views on Mentoring and Newly Qualified Teachers' Needs.” Education Inquiry 5 (2): 285-299. doi:10.3402/edui.v5.23923.

Tang, Sylvia Y. F., Angel K.Y. Wong, and May M.H. Cheng. 2016. "Examining Professional Learning and the Preparation of Professionally Competent Teachers in Initial Teacher Education." Teachers and Teaching 22 (1): 54-69. doi:10.1080/13540602.2015.1023028.

Toom, Auli, and Jukka Husu. 2018. "Teacher's Work in Changing Educational Contexts: Balancing the Role and the Person." In The Teacher's Role in the Changing Globalizing World: Resources and Challenges Related to the Professional Work of Teaching, edited by H. Niemi, A. Toom, A. Kallioniemi, and J. Lavonen, 1-9. Leiden: Brill Sense.

Tynjälä, Päivi, Anne Virtanen, Ulla Klemola, Emma Kostiainen, and Helena RaskuPuttonen. 2016. "Developing Social Competence and Other Generic Skills in Teacher Education: Applying the Model of Integrative Pedagogy." European Journal of Teacher Education 39 (3): 368-387.

doi:10.1080/02619768.2016.1171314.

University of Helsinki. 2015. "Data Policy."

https://www.helsinki.fi/en/research/research-environment/research-data/datapolicy.

Vangrieken, Katrien, Filip Dochy, Elisabeth Raes, and Eva Kyndt. 2015. “Teacher Collaboration: A Systematic Review." Educational Research Review 15: 17-40. https://doi.org/10.1016/j.edurev.2015.04.002. 
Voss, Thamar, Wolfgang Wagner, Uta Klusmann, Ulrich Trautwein, and Mareike Kunter. 2017. "Changes in Beginning Teachers' Classroom Management Knowledge and Emotional Exhaustion during the Induction Phase." Contemporary Educational Psychology 51: 170-184. https://reader.elsevier.com/reader/sd/68FE46DF58E1200DBC7F6193BC587D7C4189E E0325C5C3921CDE837F7C0FE68B970F2AE9993630567F527AF2B26A989B.

Wei, Ruth Chung, Linda Darling-Hammond, Alethea Andree, Nikole Richardson, and Stelios Orphanos. 2009. Professional Learning in the Learning Profession: A Status Report on Teacher Development in the United States and Abroad. Dallas, TX: National Staff Development Council.

Zeichner, Ken, Michael Bowman, Lorena Guillen, and Kate Napolitan. 2016. "Engaging and Working in Solidarity with Local Communities in Preparing the Teachers of Their Children.” Journal of Teacher Education 67 (4): 277-290. doi:10.1177/0022487116660623. 
Table 1. Ten most emphasized support needs for professional competences.

\begin{tabular}{|c|c|c|c|c|}
\hline \multicolumn{3}{|c|}{ School leaders } & \multicolumn{2}{|l|}{ Newly qualified teachers } \\
\hline 1 & $\begin{array}{l}\text { 7. Working with a student } \\
\text { welfare group }\end{array}$ & $\begin{array}{l}M=3.85 \\
S D=0.747\end{array}$ & $\begin{array}{l}\text { 37. Acting in conflict situations } \\
\text { (e.g. mobbing) }\end{array}$ & $\begin{array}{l}\mathrm{M}=3.59 \\
\mathrm{SD}=1.017\end{array}$ \\
\hline 2 & $\begin{array}{l}\text { 37. Acting in conflict } \\
\text { situations (e.g., mobbing) }\end{array}$ & $\begin{array}{l}M=3.79 \\
S D=0.746\end{array}$ & 12. Differentiating teaching & $\begin{array}{l}\mathrm{M}=3.50 \\
\mathrm{SD}=1.015\end{array}$ \\
\hline 3 & $\begin{array}{l}\text { 2. Managing classroom } \\
\text { interaction }\end{array}$ & $\begin{array}{l}M=3.64 \\
S D=0.799\end{array}$ & $\begin{array}{l}\text { 7. Working with a student } \\
\text { welfare group }\end{array}$ & $\begin{array}{l}M=3.35 \\
S D=0.932\end{array}$ \\
\hline 4 & 18. Cooperation with parents & $\begin{array}{l}M=3.62 \\
\mathrm{SD}=0.828\end{array}$ & $\begin{array}{l}\text { 27. Revising students' learning } \\
\text { environments }\end{array}$ & $\begin{array}{l}\mathrm{M}=3.26 \\
\mathrm{SD}=1.028\end{array}$ \\
\hline 5 & $\begin{array}{l}\text { 3. Evaluating and grading } \\
\text { students }\end{array}$ & $\begin{array}{l}M=3.42 \\
S D=0.759\end{array}$ & $\begin{array}{l}\text { 30. Evaluating students' } \\
\text { learning capacity }\end{array}$ & $\begin{array}{l}M=3.26 \\
\mathrm{SD}=0.941\end{array}$ \\
\hline 6 & 12. Differentiating teaching & $\begin{array}{l}M=3.41 \\
S D=0.866\end{array}$ & $\begin{array}{l}\text { 38. Developing applications of } \\
\text { modern information technology }\end{array}$ & $\begin{array}{l}\mathrm{M}=3.19 \\
\mathrm{SD}=1.120\end{array}$ \\
\hline 7 & $\begin{array}{l}\text { 30. Evaluating students' } \\
\text { learning capacity }\end{array}$ & $\begin{array}{l}M=3.39 \\
S D=0.852\end{array}$ & $\begin{array}{l}\text { 3. Evaluating and grading } \\
\text { students }\end{array}$ & $\begin{array}{l}\mathrm{M}=3.19 \\
\mathrm{SD}=1.061\end{array}$ \\
\hline 8 & $\begin{array}{l}\text { 8. Developing the student's } \\
\text { whole personality }\end{array}$ & $\begin{array}{l}M=3.37 \\
S D=0.778\end{array}$ & $\begin{array}{l}\text { 6. Administrative tasks } \\
\text { (information letters, reports, } \\
\text { student transfers to other groups } \\
\text { or schools, work diaries) }\end{array}$ & $\begin{array}{l}M=3.17 \\
S D=0.958\end{array}$ \\
\hline 9 & $\begin{array}{l}\text { 11. Developing the school } \\
\text { curriculum }\end{array}$ & $\begin{array}{l}M=3.33 \\
S D=0.908\end{array}$ & $\begin{array}{l}\text { 11. Developing the school } \\
\text { curriculum }\end{array}$ & $\begin{array}{l}M=3.11 \\
S D=0.929\end{array}$ \\
\hline 10 & $\begin{array}{l}\text { 10. Confronting school's } \\
\text { changing circumstances }\end{array}$ & $\begin{array}{l}M=3.32 \\
S D=0.839\end{array}$ & 34. Self-regulated learning & $\begin{array}{l}\mathrm{M}=3.03 \\
\mathrm{SD}=1.030\end{array}$ \\
\hline
\end{tabular}


Table 2. Differences between school leaders' and new teachers' mean values of professional competences and results of the t-tests (significant at $1 \%$ level).

\begin{tabular}{|c|c|c|c|}
\hline Professional competences & $\begin{array}{l}\text { Principals } \\
(\mathrm{N}=104)\end{array}$ & $\begin{array}{l}\text { New } \\
\text { teachers } \\
(N=145)\end{array}$ & $t$ \\
\hline 1. Using teaching methods & $2.73(.947)$ & $2.83(.905)$ & -.874 \\
\hline 2. Managing classroom interaction & $3.64(.799)$ & $2.97(1.151)$ & $5.490 *$ \\
\hline 3. Evaluating and grading students & $3.42(.759)$ & $3.19(1.061)$ & 2.054 \\
\hline $\begin{array}{l}\text { 4. Management of tasks outside the classroom (monitoring students } \\
\text { during their breaks etc.) }\end{array}$ & $3.17(.830)$ & $2.26(.972)$ & $7.950 *$ \\
\hline 5. Working in a school community with teachers and other school staff & $3.13(.809)$ & $2.06(.911)$ & $9.570^{*}$ \\
\hline 6. Administrative tasks (information letters, reports, etc.) & $3.31(.837)$ & $3.17(.958)$ & 1.217 \\
\hline 7. Working with a student welfare group & $3.85(.747)$ & $3.35(.932)$ & $4.639 *$ \\
\hline 8. Developing the student's whole personality & $3.38(.778)$ & $2.99(1.133)$ & 3.152 \\
\hline 9. Developing one's own educational philosophy & $3.27(.766)$ & $2.45(.950)$ & $7.537 *$ \\
\hline 10. Confronting school's changing circumstances & $3.32(.839)$ & $2.95(1.043)$ & 2.954 \\
\hline 11. Developing the school curriculum & $3.33(.908)$ & $3.11(.929)$ & 1.832 \\
\hline 12. Differentiating teaching & $3.41(.866)$ & $3.50(1.015)$ & -.677 \\
\hline 13. Preparing students for daily life & $3.28(.841)$ & $2.70(.973)$ & $4.866^{*}$ \\
\hline 14. Preparing students for future society & $3.18(.901)$ & $2.91(1.006)$ & 2.199 \\
\hline 15. Intercultural education & $2.74(.836)$ & $2.47(.943)$ & 2.394 \\
\hline 16. Promoting equity of the sexes & $2.61(.852)$ & $2.22(.878)$ & 3.455 \\
\hline 17. Self-evaluation of one's own teaching & $3.18(.879)$ & $2.79(.957)$ & 3.278 \\
\hline 18. Cooperation with parents & $3.62(.828)$ & $2.73(.915)$ & 7.953* \\
\hline 19. Planning one's teaching & $2.65(.845)$ & $2.41(.976)$ & 2.023 \\
\hline 20. Independent management of teachers' tasks & $2.57(.810)$ & $1.94(.840)$ & $5.855^{*}$ \\
\hline 21. Becoming aware of the ethical basis of the teaching profession & $2.65(.932)$ & $1.95(.811)$ & $6.184 *$ \\
\hline 22. Commitment to the teaching profession & $2.56(.993)$ & $1.92(.862)$ & $5.298 *$ \\
\hline 23. Lifelong professional growth & $2.76(.950)$ & $2.30(.994)$ & $3.693 *$ \\
\hline 24. Critical assessment of teacher education & $2.41(.931)$ & $2.04(.957)$ & 3.061 \\
\hline 25. Working as a change agent in society & $2.73(.968)$ & $2.41(.975)$ & 2.593 \\
\hline 26. Cooperative action research & $2.44(.974)$ & $2.26(1.067)$ & 1.316 \\
\hline 27. Revising students' learning environments & $3.02(.995)$ & $3.26(1.028)$ & -1.864 \\
\hline 28. Postgraduate studies in education & $2.39(.949)$ & $2.33(1.106)$ & .483 \\
\hline 29. Researching one's own work & $2.79(.910)$ & $2.26(.993)$ & $4.269 *$ \\
\hline 30. Evaluating students' learning capacity & $3.39(.852)$ & $3.26(.941)$ & 1.195 \\
\hline 31. Mastering the curriculum's academic content & $2.73(.988)$ & $2.35(.976)$ & 3.008 \\
\hline 32. Confronting multiculturalism & $3.05(.969)$ & $2.70(.967)$ & 2.826 \\
\hline 33. Readiness for media education & $2.79(.931)$ & $2.83(1.056)$ & -.303 \\
\hline
\end{tabular}




\begin{tabular}{llll}
\hline 34. Self-regulated learning & $3.03(.908)$ & $3.03(1.030)$ & -.045 \\
\hline 35. Critical reflection on one's own work & $2.98(.870)$ & $2.43(.927)$ & $4.755^{*}$ \\
\hline 36. Supporting the learner's individual growth & $3.30(.774)$ & $2.92(.958)$ & 3.284 \\
\hline 37. Acting in conflict situations (e.g., mobbing) & $3.79(.746)$ & $3.59(1.017)$ & 1.748 \\
\hline 38. Developing applications of modern information technology & $2.78(.985)$ & $3.19(1.120)$ & -3.025 \\
\hline 39. Cooperation with representatives of work life & $3.13(.946)$ & $2.69(1.024)$ & 3.490 \\
\hline 40. Cooperation with representatives of cultural life & $2.85(.943)$ & $2.50(.987)$ & 2.809 \\
\hline
\end{tabular}

Note: Data are shown as mean (SD)

$* p<.001$. 
Table 3. Themes of professional competences appeared in school leaders' and new teachers' descriptions.

Themes of professional competences

\begin{tabular}{|c|c|c|c|c|c|}
\hline Teaching and pedagogy & $\begin{array}{l}\text { Supporting students' } \\
\text { comprehensive individual }\end{array}$ & $\begin{array}{l}\text { Professional identity and } \\
\text { growth }\end{array}$ & Independent working & $\begin{array}{l}\text { Work in a school } \\
\text { community }\end{array}$ & $\begin{array}{l}\text { Collaboration with out- } \\
\text { of-school-partners }\end{array}$ \\
\hline
\end{tabular}
growth

- M anaging classroom interactions

- Implementing the curriculum

- Designing teaching

- Knowledge of new and versatile teaching and working methods

- Subject knowledge

- Competence for evaluation

- Knowledge of new learning environments
- Developing professional identity

- Reflecting and developing one's own work and competences

- Knowledge of special education

- Knowledge of student welfare services and models

- Multicultural competence
- Acting independently in complex, challenging and unexpected situations

- Accountability and responsibility

- Finding own ways of teaching

- Setting boundaries for one's own work and accepting own

professional

incompleteness
- Work tasks outside a classroom

- Getting familiar with the school

culture

- Interaction and collaboration among colleagues

- Renewing and developing objectives and practices of the school community
- Collaboration with other teachers and professionals

- Collaboration with parents or custodians

- Collaboration with community members 